\title{
A review of methods for monitoring streamflow for sustainable water resource management
}

\author{
Pariva Dobriyal $^{1} \cdot$ Ruchi Badola $^{1} \cdot$ Chongpi Tuboi $^{1} \cdot$ Syed Ainul Hussain $^{1}$
}

Received: 29 May 2015/Accepted: 10 October 2016/Published online: 31 October 2016

(C) The Author(s) 2016. This article is published with open access at Springerlink.com

\begin{abstract}
Monitoring of streamflow may help to determine the optimum levels of its use for sustainable water management in the face of climate change. We reviewed available methods for monitoring streamflow on the basis of six criteria viz. their applicability across different terrains and size of the streams, operational ease, time effectiveness, accuracy, environmental impact that they may cause and cost involve in it. On the basis of the strengths and weaknesses of each of the methods reviewed, we conclude that the timed volume method is apt for hilly terrain having smaller streams due to its operational ease and accuracy of results. Although comparatively expensive, the weir and flume methods are suitable for long term studies of small hill streams, since once the structure is put in place, it yields accurate results. In flat terrain, the float method is best suited for smaller streams for its operational ease and cost effectiveness, whereas, for larger streams, the particle image velocimetry may be used for its accuracy. Our review suggests that the selection of a method for monitoring streamflow may be based on volume of the stream, accuracy of the method, accessibility of the terrain and financial and physical resources available.
\end{abstract}

Keywords Ecosystem services - Water resource management $\cdot$ Streamflow monitoring $\cdot$ Fresh water . Climate change

Electronic supplementary material The online version of this article (doi:10.1007/s13201-016-0488-y) contains supplementary material, which is available to authorized users.

Syed Ainul Hussain

hussain@wii.gov.in

1 Wildlife Institute of India, Post Box \# 18, Chandrabani, Dehra Dun 248001, Uttarakhand, India

\section{Introduction}

The availability and distribution of freshwater is of grave concern, since only $2.5 \%$ of it covers the earth's surface, only a fraction of which is accessible via lakes, reservoirs and river systems (Berner and Berner 2012). Freshwater plays multiple roles as supporting, regulating, provisioning and recreational services (Millennium Ecosystem Assessment 2005; Smith et al. 2006; Greiber 2009; Gleick 2014) (Table 1). Considering the importance of freshwater systems to human well-being, natural processes and properties that maintain freshwater ecosystems need to be monitored at both local and global scales (Karr 1991; United Nations 2011). Alteration in the natural systems due to human or natural activities may affect the hydrological regime, which in turn affects the ecosystem level processes that affect the availability of water resources (Vogel et al. 2015; Bonacci et al. 2015). Change in water regimes can occur due to decreased or increased availability of water through precipitation, runoffs, groundwater recharge and discharge. This may also be affected by seasonality, frequency, duration, magnitude and timing of flow events (Beavis et al. 2010).

The availability of water affects the natural process such as the ability of soil to retain and purify water, frequency and rate of recharge, which eventually changes the local or regional vegetation type. The alteration in the hydrological regime is considered as a major factor contributing to the loss of biological diversity and ecological functioning of aquatic ecosystems (Bunn and Arthington 2002; Dale et al. 2016). There is substantial uncertainty in trends of hydrological variables due to large regional differences and limitations of the spatiotemporal monitoring networks (Bates et al. 2008; Baltas 2009). 
Table 1 Water-related ecosystem services (modified from: Smith et al. 2006; Greiber 2009)

\begin{tabular}{|c|c|c|}
\hline Type of service & Description & Example \\
\hline $\begin{array}{l}\text { Provisioning } \\
\text { services }\end{array}$ & $\begin{array}{l}\text { Direct supply of food and non-food products depending } \\
\text { on water flow }\end{array}$ & $\begin{array}{l}\text { 1. Access to freshwater } \\
\text { 2. Agricultural production } \\
\text { 3. Livestock production } \\
\text { 4. Fisheries and marine products } \\
\text { 5. Production of hydro-electric power } \\
\text { 6. Water transport trade }\end{array}$ \\
\hline $\begin{array}{c}\text { Regulating } \\
\text { services }\end{array}$ & Related to regulating flows and reducing hazards & $\begin{array}{l}\text { 1. Buffering of runoff soil water infiltration ground water, } \\
\text { maintenance of base flows } \\
\text { 2. Regulation of soil nutrient } \\
\text { 3. Prevention of disaster, i.e. landslide, flood, land erosion drought } \\
\text { (risk management) } \\
\text { 4. Regulation of surface and ground water } \\
\text { 5. Regulating micro-climate }\end{array}$ \\
\hline $\begin{array}{c}\text { Supporting } \\
\text { services }\end{array}$ & Provided support to habitats and ecosystem functioning & $\begin{array}{l}\text { 1. Stabilizing wildlife habitats } \\
\text { 2. Upholding flow required to maintain downstream habitat and uses }\end{array}$ \\
\hline Cultural services & Related to reservation and human inspiration & $\begin{array}{l}\text { 1. Aquatic recreation } \\
\text { 2. Landscape esthetic } \\
\text { 3. Cultural heritage and identity } \\
\text { 4. Religious value (sacred pond, rivers) }\end{array}$ \\
\hline
\end{tabular}

Streamflow, in developed nations, is being monitored since late nineteenth century for better management and allocation of water resources (Barrows 1998), while in developing countries, streamflow monitoring is largely understudied. Monitoring streamflow can potentially be used to study the impact of climate change on water resources, help understand trends of natural hazards, e.g, flash floods, cloudbursts, landslides, rockslides and avalanches, and can be applied for the assessment of freshwater services or water retained by different landscapes (Table 1) (Naithani et al. 2001; Mazari and Sah 2004; Haritashya et al. 2006; Huntington 2006; Mata and Budhooram 2007; Chen et al. 2014). It can provide baseline information about the status and trend in water resource degradation. Since effective management practices in smaller and larger areas can restore degraded ecosystems, measuring flow is significant as it provides information for effective policy and management interventions for efficient economic and ecological water allocation, e.g., extraction and allocation of resources for agriculture and domestic uses and relief management, activities to meet the immediate needs during natural hazards such as landslide, land erosion, flood and drought. It can also be used as a tool to understand the contribution of water to economic development and human well-being (Acreman 2001), enabling societies to allocate water to its highest social value (Moran and Dann 2007) (Fig. 1). Efficient economic allocation of water ensures the availability of water resources for direct human use such as drinking, domestic use, agricultural use, etc., while, efficient ecological water allocation ensures availability of resources for indirect human use in terms of provision of several ecosystem services that support human society (Acreman 2001; Reddy et al. 2015). However, most of the studies on stream monitoring focus on run-off and soil erosion estimation. Some key previous studies have been summarized in Table S1.

The main objective of this review was to compare the various techniques of streamflow monitoring and identify the most suitable methods for monitoring streams of varied sizes across different terrains in developing countries. These methods can then be used for (a) quantification of available water resources, and (b) identification and mapping for the payment of freshwater services provided by different landscapes, especially the water retained by the different forest types. This paper brings together the current technical knowledge for successful implementation of water resources management strategies in developing countries. In the developing countries scenario, most of the managers have access to cheap human resource (mainly untrained and unskilled labor) but lack technical infrastructure and accessibility to monitoring sites due to harsh weather conditions and low connectivity.

\section{Methods}

We first gathered literature on streamflow and its measurement through online web based search engines, using keywords such as, streamflow, stream discharge, direct 
Fig. 1 Implication of stream flow monitoring for policy and financial management

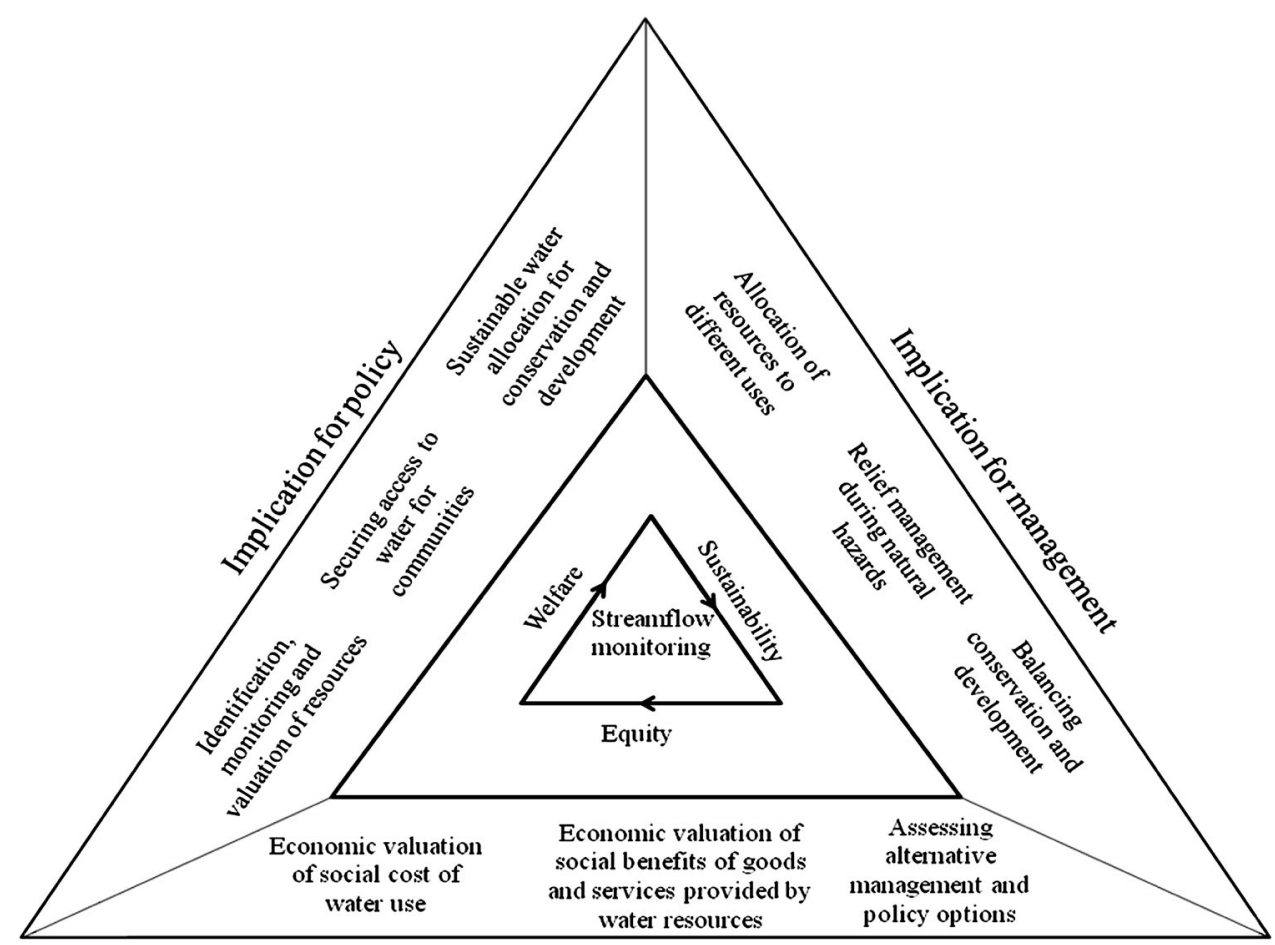

Implication for economic efficiency of water allocation measurement method of stream discharge monitoring, velocity-area method, formed constriction, constricted flow methods, current meters, timed volume method, float method, dilution gauging, trajectory method, weir method, flume method, water resource monitoring and sustainable water identification and management. Web-based resources and online technical databases such as ScienceDirect, JSTOR, Wiley Online Library and Google Scholar were searched and relevant literature was downloaded. The literature thus collected was thoroughly reviewed and six criteria viz. terrain of the stream, accuracy, cost effectiveness, operational ease, time efficiency and impact on environment were identified (Baker 1990; Mittelbach et al. 2012) to compare the methods and a comparison matrix was prepared (Dobriyal et al. 2012; Qureshi et al. 2012) (Table 2). For the present work, terrain of the stream is whether stream is in hills or in flat terrain; accuracy is the degree to which results are free from error; operational ease is the simplicity of data collection in the field and data analysis afterwards; cost effectiveness refers to relative costs incurred in the operation and maintenance of a particular method; time efficiency is the time taken for data collection for one reading and its analysis and to maintain the equipment used; impact on environment is the impact of technique or method on the surrounding environment and wildlife. The criteria were measured against a binary index by assigning one point for advantageous quality and zero if a criterion was not fulfilled by the particular method. Differential weights were subjectively accorded to these above-mentioned criteria in accordance with the importance. The final score was the product of the weights of the criteria and the index value of the method for that particular criterion (Table 3).

\section{Review of methods used for streamflow monitoring}

Methods for streamflow monitoring are specific to stream types. Stream channels can be classified on the basis of eight major variables-width, depth, velocity, discharge, slope, roughness of bed and bank materials, sediment load and sediment size (John 1978; Singh 2003). Different methods are available to quantify and monitor the surfacewater flow. The methods have been grouped into four categories (based on John 1978; Martin 2006; Herschy 2008; Şengörür et al. 2014): (a) direct measurement methods, (b) velocity-area methods, (c) formed constriction or constricted flow methods, and (d) non-contact measurement methods (Fig. 2). A succinct description of methods has been summarized in Table S2, with a brief account of their suitability to different terrains, advantages and disadvantages. A method can be selected on the basis of the volume of water to be measured, the degree of accuracy desired, whether the installation is permanent or temporary and the financial investment required (Tobias et al. 2001; Parker et al. 2004). 


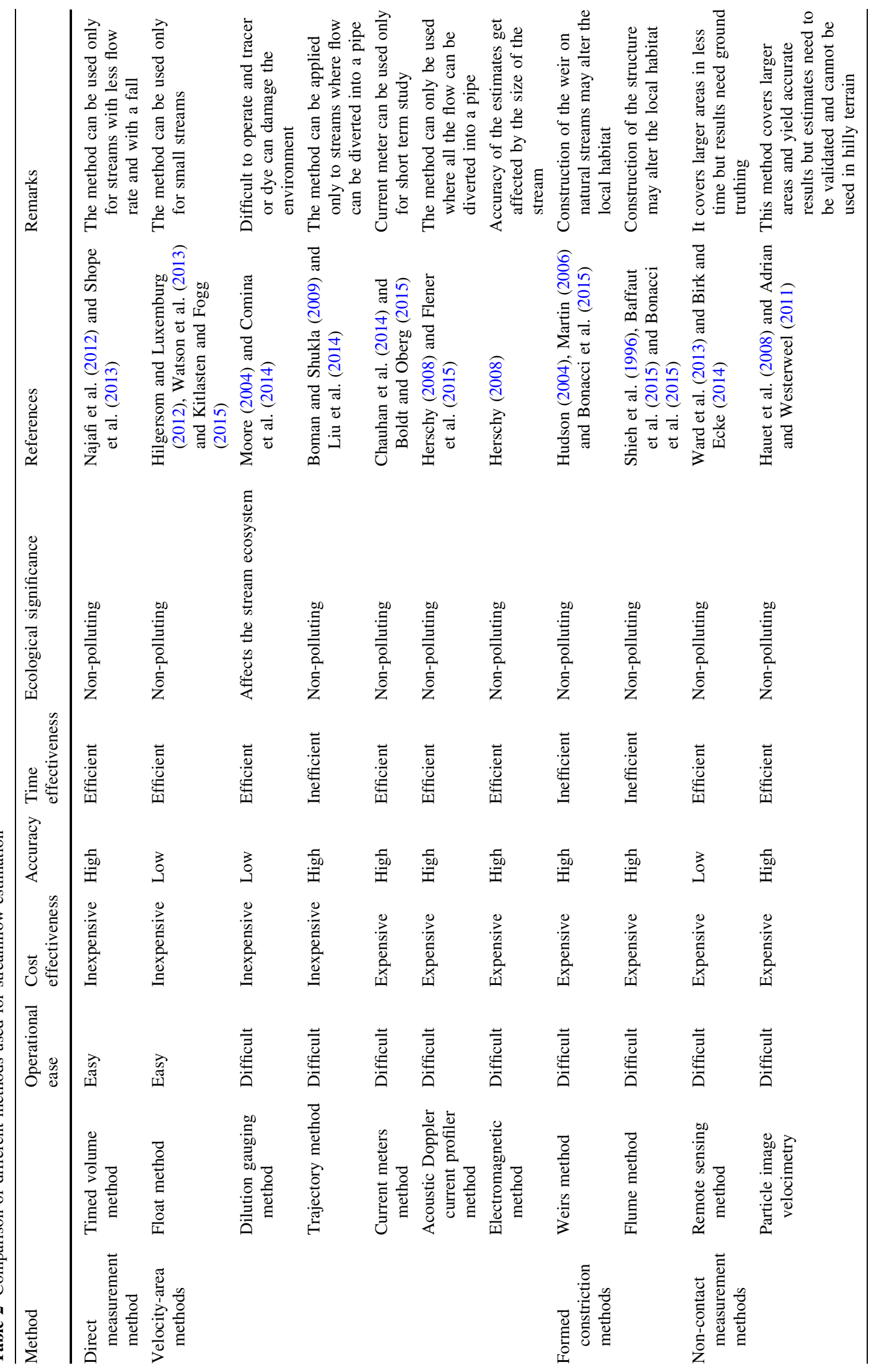


Table 3 Binary index developed for the different methods against identified criteria

\begin{tabular}{|c|c|c|c|c|c|c|c|c|c|c|c|}
\hline $\begin{array}{l}\text { Different } \\
\text { Criteria } \\
\text { (weight) }\end{array}$ & $\begin{array}{l}\text { Timed } \\
\text { volume } \\
\text { method }\end{array}$ & $\begin{array}{l}\text { Float } \\
\text { method }\end{array}$ & $\begin{array}{l}\text { Dilution } \\
\text { gauging } \\
\text { method }\end{array}$ & $\begin{array}{l}\text { Trajectory } \\
\text { method }\end{array}$ & $\begin{array}{l}\text { Current } \\
\text { meter }\end{array}$ & $\begin{array}{l}\text { ADCP } \\
\text { method }\end{array}$ & $\begin{array}{l}\text { Electromagnetic } \\
\text { method }\end{array}$ & $\begin{array}{l}\text { Weir } \\
\text { method }\end{array}$ & $\begin{array}{l}\text { Flume } \\
\text { method }\end{array}$ & $\begin{array}{l}\text { Remote } \\
\text { sensing }\end{array}$ & $\begin{array}{l}\text { Particle } \\
\text { image } \\
\text { velocimetry }\end{array}$ \\
\hline $\begin{array}{l}\text { Operational } \\
\text { ease (2) }\end{array}$ & 2 & 2 & 0 & 0 & 0 & 0 & 0 & 0 & 0 & 0 & 0 \\
\hline $\begin{array}{l}\text { Cost } \\
\text { effectiveness } \\
\text { (2) }\end{array}$ & 2 & 2 & 2 & 2 & 0 & 0 & 0 & 0 & 0 & 0 & 0 \\
\hline Accuracy (2) & 2 & 0 & 0 & 2 & 2 & 2 & 2 & 2 & 2 & 2 & 2 \\
\hline $\begin{array}{l}\text { Time } \\
\text { effectiveness } \\
\text { (2) }\end{array}$ & 2 & 2 & 2 & 0 & 2 & 2 & 2 & 0 & 0 & 2 & 2 \\
\hline $\begin{array}{l}\text { Impact on } \\
\text { environment } \\
\text { (3) }\end{array}$ & 3 & 3 & 0 & 3 & 3 & 3 & 3 & 3 & 3 & 3 & 3 \\
\hline Total weight & 11 & 9 & 4 & 7 & 7 & 7 & 7 & 5 & 5 & 7 & 7 \\
\hline
\end{tabular}

One index value was given to a method for presence of the desired quality and zero if that criterion was not fulfilled by the method. Weight has been given to the different criteria in accordance with the importance of it, subjectively. Final scores were the product of weightage of the criteria and index value of the method for that particular criterion

\section{Direct measurement method}

\section{Timed volume or volumetric streamflow method}

This method is used for streams where the entire flow converges into a single descend (Hauer and Lamberti 2007; Shope et al. 2013). The time required to fill a container of a known volume is recorded and later used to calculate the average flow rate (Lawson 1995). For reliable and accurate results, container must be of a large size and the flow rate measured at least five times, with more than three replicates for the stream width and depth recorded (Ely 1994; Pfeffer and Wagenet 2007). The flow rate is the ratio of average stream cross section area and average time taken to fill the container. This method is accurate, cost and time effective, non-polluting and requires limited resources and technical knowledge (Friederich and Smart 1982; Najafi et al. 2012). However, this method is suitable only for small and narrow streams (Weight and Sonderegger 2001; Shope et al. 2013).

\section{Velocity-area methods}

Velocity-area methods are based on the principle of the continuity of fluid flow. These methods are used for instantaneous measurement of streamflow and to establish the stage-discharge relationship (Harmel et al. 2009).

\section{Float method}

In the float method, an object of low density is allowed to float for a known distance in the stream, and the time taken by the float is measured and water speed calculated (Hauet et al. 2008; Gordon et al. 2013). The speed of water and the cross-sectional area is used for calculating the water flow in the stream (Peltz and Schwartz 2008). To overcome error, 5-10 floats should be recorded. The floats should ideally be made of materials such as a water-soaked block of wood, or other natural material that has less per unit area mass and can be easily spotted from a distance (Harrelson et al. 1994; Harwell and Asquith 2011). This is a simple, nonpolluting method and does not require extensive resources and high skills (Grant and Brian 1997; Hauer and Lamberti 2007). However, the results are often inaccurate because vertical turbulent motion causes the difference between the velocity of different surfaces of streams and float does not represent the actual flow (Hilgersom and Luxemburg 2012). This method is suitable for small and straight streams or canals with low and even flow (Hudson 1993); its applicability for larger streams is questionable. To overcome this, the integrated float method has been developed (Herschy 1978, 1995; Hilgersom and Luxemburg 2012), where a float is released at the bottom of a river or canal. The float is assumed to rise with a constant velocity, so the depth-integrated horizontal velocity can be determined from the float's displacement as it surfaces (Hilgersom and Luxemburg 2012).

\section{Dilution gauging method}

Dilution gauging method measures streamflow on the basis of rate of diffusion of a tracer that can be either a chemical or a radio isotope (Comina et al. 2014; Dingman 2015). Chemical tracers, such as common salt $(\mathrm{NaCl})$, can be used by using an electrical conductivity (EC) meter or an ion electrode (Flury and Wai 2003; Otz et al. 2003). 
Fig. 2 Existing methods used for stream monitoring (categorized on the basis of principle)
Categories of methods

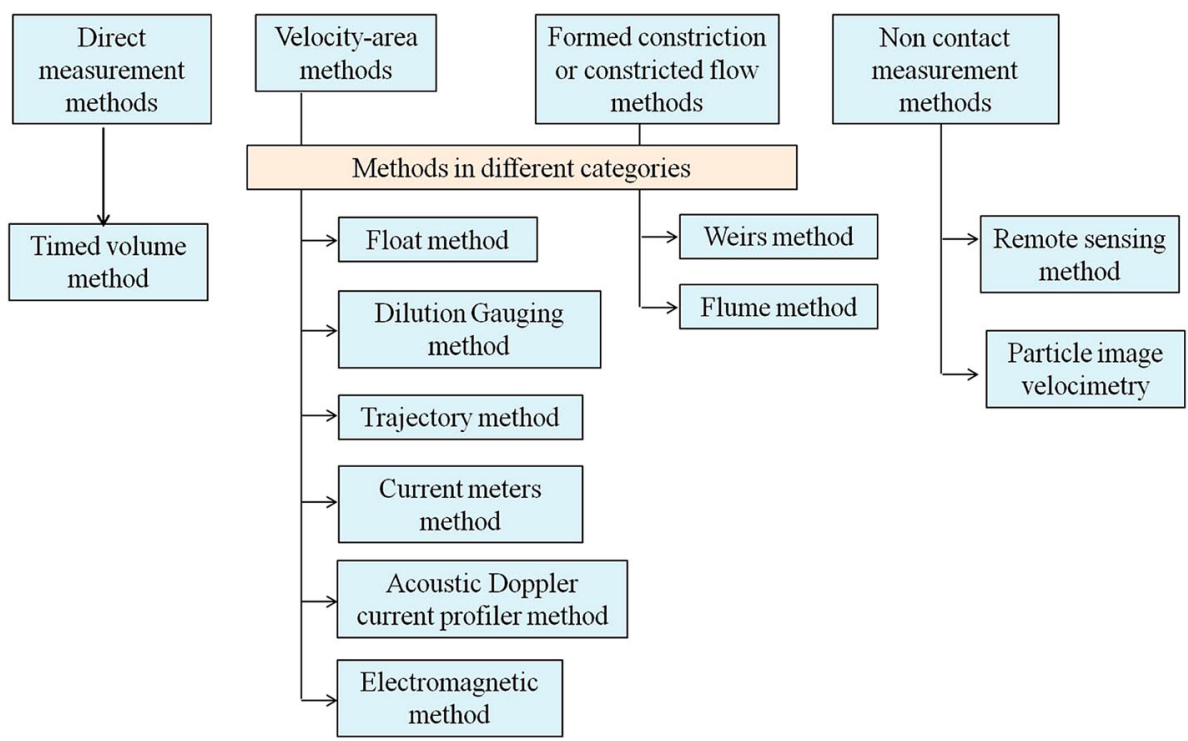

Streamflow is calculated by multiplying average cross section area and velocity of the flow. The method is inexpensive. It is an absolute method because the discharge is computed from volume and time only (Herschy 2008). It is used in turbulent flow conditions where conventional methods are difficult to apply (Gordon et al. 2004). However, the method can report erroneous results due to the loss and incomplete mixing of the tracer arising from the difference in velocity in the upper and lower surfaces of the stream. Special training is needed to apply this method in the field. In certain areas, it is difficult to obtain the permission to inject tracers into streams as it can pollute water (Moore 2004).

\section{Trajectory method}

In the trajectory method, all the flow in a stream is diverted into a pipe (Yan 1996; Hudson 2004; Salguero et al. 2008). Flow from a horizontal pipe can be estimated using either the California pipe method developed by van Leer (1924) or the trajectory method developed by Greeve (1928). This flow measurement technique is based on measuring brink depth at the end of the pipe (Berkowitz 2013). The diverted water is discharged with pressure so that the rate of flow can be estimated from measurements of the jet (Rohwer 1943; Boman and Shukla 2009). At least two measurements of the discharging jet are required to calculate the rate of flow of the water (Yan 1996; Liu et al. 2014). The method provides reasonably accurate values of discharge only for certain ranges of size and flow conditions and can be applied to streams where discharge can be diverted through a pipe (Hudson 1993; Boman and Shukla 2009).
This method can be adapted for the measurement of discharge in small open channels where flow can be directed to a pipe (Liu et al. 2014). This method needs trained man power and involves complicated calculations (Boman and Shukla 2009).

\section{Current meter method}

The current meter method depends on defined channel geometry for the calculation of flow velocities (Briggs et al. 2012; Hamilton and Moore 2012). The current meter measures a point velocity or a velocity field directly. The cross-sectional geometry (channel geometry) is needed to convert the velocity to a discharge. In this method, stream channel cross section is divided into vertical subsections. Area for each subsection is calculated by measuring the average width and depth. The velocity of flow at a point is proportional to the rate of rotation of the rotor during a fixed period of time (Soupir et al. 2009; Chauhan et al. 2014). The discharge is a product of area and measured velocity and is calculated for each subsection. Total discharge is the sum of discharge of subsections. The current meter method is accurate, time effective and suitable for hilly terrains (United States Geological Survey 2007) and so can be used commercially (United States Department of Agriculture 2001). Current meters are expensive and can be used only for a short period.

\section{Acoustic Doppler current profiler method}

Acoustic Doppler current profiler method (ADCPs) transmits sound into the water and receives echoes from 
particles suspended in the stream. The difference in the frequency of the transmitted sound and echoes is used to calculate the velocities of the particles and the water in which they are suspended (Costa et al. 2000, 2006). Mounted on a ship or a boat, ADCPs provide the quasicontinuous vertical profile of horizontal current (Muste et al. 2004; Chauhan et al. 2014). It measures boat speed and direction by tracking the river bottom and compensate for the boat movement in the computation of water velocities (Oberg and Mueller 2007). ADCPs can be classified into two classes on the basis of the techniques used to configure and process the acoustic signal-narrowband and broadband (Lu and Lueck 1999; Lee et al. 2014). ADCP method measures the stream discharge faster and yields accurate results because ADCPs measure a much larger portion of the water column (Mueller and Wagner 2009). It is non-invasive but costly and needs trained personnel, for if used with inappropriate techniques it may give inaccurate results, and is suitable only for large streams and rivers in flat terrains (Visbeck 2001; Flener et al. 2015). However, the ADCP equipment may be deployed by the use of a tethered boat, or small powered launches or catamarans, where, with the aid of two operators, this method can be used for small rivers (Herschy 2008; Flener et al. 2015). Acoustic velocity meters (AVMs) are not related to the float method. AVMs measure the flow velocity across the channel at one or more fixed levels and an index velocity rating is used to convert this velocity to the cross-sectional average velocity that is used to compute discharge. Some simple, narrow-beam acoustic Doppler velocity meters (ADVMs) measure velocity at a single point in the flow and relate this to the cross-sectional average velocity.

\section{The electromagnetic method}

The electromagnetic method measures point velocity of a stream by using an electromagnetic meter. Continuous records of velocity at one point in a cross section and of the stage readings are used to calculate the stream discharge records (Egusa et al. 2013). This method works according to Faraday's law of electromagnetic induction, the motion of water flowing in a stream cuts the vertical component of the earth's magnetic field and an electromotive force (EMF) is induced in the water. This EMF can be sensed by electrodes ('probes') on each side of the stream and is found to be directly proportional to the average velocity of flow in the cross section (Herschy 2008). This method gives accurate results but special training is needed to use the probes (Ryckborst and Christie 1977; Van Gent et al. 2008). Electromagnetic method gives reliable results only for streams where all the flow can be diverted into a pipe (Herschy 2008).

\section{Formed constriction methods}

These methods are less influenced by the roughness of the stream and the backwater influence, compared to the velocity-area methods. All formed constriction methods are generally appropriate for small streams.

\section{Weir method}

In this method, stream discharge is estimated using a formed check-dam or weir made of plywood, or other wooden boards, and reinforced concrete, in the cross section of a stream (Rickard et al. 2003; Gordon et al. 2013). Weirs are classified into two general categories viz. broad crested and sharp crested (Chaudhry 2008). Broad crested weirs can only be used to calculate instantaneous flows (Gonzalez and Chanson 2007). Sharp crested weirs are constructed in a variety of shapes such as V-notch, rectangular and Cipolletti weirs (Martin 2006). Flow rate can be measured by using a predefined table (British Columbia 2006) or discharge can be estimated using a weir equation, which considers the flow rate, height of water head and width of the crest (Ghodsian 2003; Emiroglu et al. 2011). This method requires skilled workers (Peterson and Cromwell 1993) and considerable drop between the upstream and downstream water surfaces, which is often not available in flat grade ditches. Frequently, it is necessary to construct a pool or stilling area above the weir so the water loses its velocity. Weir installations in earthen ditches can be troublesome and results can be affected by installation and construction (Peterson and Cromwell 1993; George et al. 2011). This method is time consuming, expensive and installation of weirs may alter the habitat for local species (Rickard et al. 2003). Siltation affects the reliability of the results (Hudson 2004). A premeasured flow rate is needed before constructing a weir (Martin 2006). The weir must be sized to accommodate the range of flow that needs to be measured. In many cases, the natural range of flow is too large to be captured by a single weir. Compound weirs can be used to expand the measured range of flows. Weirs are one of the most accurate methods of measuring water flow (Peterson and Cromwell 1993) and may form an important component of a Water Management Plan (Rickard et al. 2003).

\section{Flume method}

A flume is an artificial open channel flow section that restricts the stream area and changes its slope, which increases the velocity and changes the volume of the water flowing through the flume (Ancey et al. 2008). There is no impoundment, but the height of water in the flume is measured with a stilling well (Mutz et al. 2007). The discharge can be calculated by measuring the height of water 
in the flume. HS, H and HL type flumes are used for measuring intermittent runoff, venturi flume for measuring irrigation water and San dimas Flume for debris laden flows in mountain streams (USFWS 2006). For water flow calculations, tables given by Bos (1976) and Hudson (1993) can be used. Flumes give accurate results when properly manufactured and installed (Hudson 2004) and do not need calibration, but accuracy gets affected by approach velocity of liquid and siltation (Hudson 2004). This method is not suitable for streams with large amount of debris, sediment or solids. Construction and installation are difficult (Shieh et al. 1996; Baffaut et al. 2015). Flumes are not practical except for small streams and are more limited than weirs regarding the range of flows that can be measured. Additionally, flume construction is more difficult than weirs.

The ultrasonic method is particularly applicable to rivers up to about $300 \mathrm{~m}$ or more in width, where (a) there is no stable stage-discharge relation, and (b) a measuring structure is unsuitable or not feasible. The method is therefore appropriate under conditions of backwater from dams, tides, or other causes, and where the installation of a measuring structure would either prove too expensive or sufficient afflux, or head, is not available. Ultrasonic river gauging is based on the continuous measurement of stream velocity at chosen depths by recording the difference in time for sound pulses sent obliquely across the river in opposite direction.

\section{Non-contact measurement methods}

Most of the above-mentioned methods are feasible in accessible terrains. The non-contact methods can be used for the streams which are not easily accessible. These methods are based on the principle of radar system and may be used to make continuous, near-real-time flow measurements during high and medium flows.

\section{Remote sensing method}

Remote sensing method estimates river discharge from space, using ground measurements and satellite data to construct empirical curves that relate water surface area to discharge (Bjerklie et al. 2005; Tan et al. 2014). The sensors used in this method can be (a) passive, in which the sensor receives energy naturally reflected by or emitted from the earth's surface; and (b) active, in which the sensor provides its own illumination and records the amount of incident energy returned from the imaged surface (Xu et al. 2004; Ticehurst et al. 2009). Three general approaches are used to estimate stream discharge: (a) direct measurement of water surface level from radar altimeter waveform data; (b) determination of water surface elevations at their point of contact with the land surface using high-resolution satellite imagery and topographic data; and (c) correlation of satellite-derived water surface areas with ground measurements of stage or discharge (Smith 1997; Papa et al. 2012; Revilla-Romero et al. 2014). Satellite data could provide unprecedented global coverage of critical hydrologic data that is logistically and economically impossible to obtain through ground-based observation networks (Koblinsky et al. 1993; Xu et al. 2004; Batra et al. 2006). Remote sensing is an expensive method and cannot directly estimate the stream discharge (Costa et al. 2000). Larger errors occur in flooded forests because trees are highly reflective in the visible and near-infrared range (Ward et al. 2013). Floating emergent macrophytes also affect the accuracy of the results in tropical systems (Hess et al. 1995; Birk and Ecke 2014). This method can be used for both flat and hilly terrain, but it can estimate the discharge of only larger streams (Immerzeel et al. 2009).

\section{Particle image velocimetry}

In the particle image velocimetry (PIV) method, the position of the fluid is represented through the light scattered by liquid or solid particles illuminated by a laser light sheet (Prasad 2000; Tauro et al. 2016). In most of the studies, liquid or solid particles have to be seeded with tracer particles that are small and light enough to move with local flow velocity (Brossard et al. 2009). A flat terrain in which flow need to be calculated illuminated twice by means of two superimposed laser light sheets. The light scattered by the liquid or solid particles is recorded on two separate frames on a CCD camera sensor (Bosbach et al. 2009). The time intervals between the two laser pulses, image magnification produced by camera calibration and projection of the local flow velocity vector onto the plane of the light sheet are used to calculate the small interrogation areas. These small interrogation areas produce one displacement vector. The velocity is the ratio of the particle displacement divided by the time interval between images (Harpold Harpold et al. 2006; Stamhuis 2006). The main advantage of PIV is that it provides high-resolution flow velocity information of a flat surface at one time (Stamhuis 2006). This method requires special training and expensive instruments to take measurements and can be applied only in flat terrains (Adrian and Westerweel 2011). PIV gives accurate results as compared to other methods but does not take direct measurement; hence, validation of results is needed for this method (Hauet et al. 2008).

\section{Conclusions}

Monitoring hydrological regimes has gained importance with the increasing concern for impacts of climate change. Stream monitoring forms a critical basis for water resource management. The volume and functions of the streams are 
controlled by hydrologic processes that can be defined by the geology, topography and climate of the area, along with impact of human activities. Understanding the streamflow and the hydrological processes determining the streamflow is critical for the efficient and optimum allocation of water resources, so as to realize their maximum social and economic value. Information generated through regular monitoring of natural streams/rivers encourages sustainable use of water resources and also facilitates development and implementation of economic tools such as payments for ecosystem services (Fig. 1). A river/stream can be monitored using a method that is appropriate for the objective of the study, resources and expertise availability, stream size and terrain. On the basis of review of literature and qualitative index developed (Table 3), we concluded that, for monitoring small mountain streams, timed volume method is apt and provides a high degree of accuracy. For mountain streams with large quantity of water, weir and flume methods are more efficient and can be used for a long term study. For small streams in flat terrain, float method can be used, whereas, for larger streams, dilution gauging is a better method if tracer is properly added to all the surfaces of the stream and if tracer does not alter water quality (Table S2). The current meter and PIV can be used for more accurate results, although this requires specialized training (Table 2). The present study suggests that the selection of a method for monitoring streamflow may be based on volume of stream, accuracy of the results, accessibility of the terrain and financial and physical resources available.

The policies related to freshwater conservation are likely to become obsolete or no longer responsive to new and changing environmental and political conditions (Woodward et al. 2010; Slate 2014). It has been observed that climate change is consistently associated with changes in a number of components of the water systems (Barnett et al. 2005; Beniston 2012). Governments and water resource managers can use stream monitoring, via prioritized methods, for gathering information needed to plan efficient allocation of freshwater resources and develop possible adaptation strategies/policies to address changing climate conditions.

Acknowledgements The present manuscript was prepared for the Project "An integrated approach to reduce the vulnerability of local community to Environmental Degradation in the Western Himalayas" funded by the Grant-in Aids funds of the Wildlife Institute of India, Dehra Dun. We thank the Director and the Dean, WII for the logistic and procedural support.

Open Access This article is distributed under the terms of the Creative Commons Attribution 4.0 International License (http:// creativecommons.org/licenses/by/4.0/), which permits unrestricted use, distribution, and reproduction in any medium, provided you give appropriate credit to the original author(s) and the source, provide a link to the Creative Commons license, and indicate if changes were made.

\section{Reference}

Acreman MC (2001) Ethical aspects of water and ecosystems. Wat Policy J 3:257-265

Adrian RJ, Westerweel J (2011) Particle image velocimetry (vol 30). Cambridge University Press, Cambridge

Ancey C, Davison AC, Bohm T, Jodeau M, Frey P (2008) Entrainment and motion of coarse particles in a shallow water stream down a steep slope. J Fluid Mech 595:83-114

Baffaut C, Sadler EJ, Ghidey F (2015) Long-term agroecosystem research in the central Mississippi river basin: goodwater creek experimental watershed flow data. J Environ Quality 44(1):18-27

Baker JM (1990) Measurement of soil water content. Remote Sens Rev 5:263-279

Baltas EA (2009) Climate change and associated implications for the water policy framework in the basin of Venetikos. Int $\mathrm{J}$ Wat Resources Develop 25(3):491-506

Barnett TP, Adam JC, Lettenmaier DP (2005) Potential impacts of a warming climate on water availability in snow-dominated regions. Nature 438(7066):303-309

Barrows CJ (1998) River basin development planning and management: a critical review. World Dev 26(1):171-186

Bates BC, Kundzewicz ZW, Wu S, Palutikof JP (eds) (2008) Climate change and water technical paper of the Intergovernmental Panel on Climate Change IPCC Secretariat, Geneva

Batra N, Islam S, Venturini V, Bisht G, Jiang LE (2006) Estimation and comparison of evapotranspiration from MODIS and AVHRR sensors for clear sky days over the Southern Great Plains. Remote Sens Environ 103(1):1-15

Beavis SG, Roberts J, Ellis DJ (2010) Water-dependent ecosystems: the ecological consequences of irrigation infrastructure refurbishment. Waterlines Report Series No 33

Beniston M (2012) Impacts of climatic change on water and associated economic activities in the Swiss Alps. J Hydrol 412:291-296

Berkowitz JF (2013) Incorporating science-based approaches into the rapid assessment of wetlands and streams: validation, restoration trajectory, and method development. Doctoral dissertation, University of California Riverside

Berner EK, Berner RA (2012) Global environment: water, air, and geochemical cycles. Princeton University Press, Princeton

Birk S, Ecke F (2014) The potential of remote sensing in ecological status assessment of coloured lakes using aquatic plants. Ecol Indicators 46:398-406

Bjerklie DM, Moller D, Smith LC, Dingman SL (2005) Estimating discharge in rivers using remotely sensed hydraulic information. J Hydrol 309(1):191-209

Boldt JA, Oberg KA (2015) Validation of streamflow measurements made with M9 and RiverRay acoustic Doppler current profilers. J Hydraul Eng: 04015054

Boman B, Shukla S (2009) Water measurement for agricultural irrigation and drainage systems. Agricultural and Biological Engineering Department, Florida Cooperative Extension Service, University of Florida

Bonacci O, Buzjak N, Roje-Bonacci T (2015) Changes in hydrological regime caused by human intervention in karst: a case of the Rumin Springs. Hydrol Sci J. doi:10.1080/02626667.2015. 1111518

Bos MG (1976) Discharge measurement structures. Publication 20 International Institute for Land Reclamation and Improvement (ILRI), Wageningen

Bosbach J, Kühn M, Wagner C (2009) Large scale particle image velocimetry with helium filled soap bubbles. Exp Fluids 46(3):539-547 
Briggs MA, Lautz LK, McKenzie JM (2012) A comparison of fibreoptic distributed temperature sensing to traditional methods of evaluating groundwater inflow to streams. Hydrol Process 26(9):1277-1290

British Columbia (2006) Water supply factsheet. Ministry of Agricultural and Lands Abbotsford, British Columbia

Brossard C, Monnier JC, Barricau P, Vandernoot FX, Le Sant Y, Champagnat F, Le Besnerais G (2009) Principles and applications of particle image velocimetry. Aerosp Lab J 1:1-11

Bunn SE, Arthington AH (2002) Basic principles and ecological consequences of altered flow regimes for aquatic biodiversity. Environ Manage 30(4):492-507

Chaudhry MH (2008) Open channel flow, 2nd edn. Springer, New York

Chauhan MS, Kumar V, Dikshit PKS, Dwivedi SB (2014) Comparison of discharge data using ADCP and current meter. Int $\mathbf{J}$ Adv Earth Sci 3(2):81-86

Chen X, Hao Z, Devineni N, Lall U (2014) Climate information based streamflow and rainfall forecasts for Huai River basin using hierarchical Bayesian modeling. Hydrol Earth Syst Sci 18(4):1539-1548

Comina C, Lasagna M, De Luca DA, Sambuelli L (2014) Geophysical methods to support correct water sampling locations for salt dilution gauging. Hydrol Earth Syst Sci 18(8):3195-3203

Costa JE, Spicer KR, Cheng RT, Haeni FP, Melcher NB, Thurman EM, Plant WJ, Keller WC (2000) Measuring stream discharge by non-contact methods-a proof-of-concept experiment. Geophys Res Lett 27(4):553-556

Costa JE, Cheng RT, Haeni FP, Melcher N, Spicer KR, Hayes E, Plant W, Hayes K, Teague C, Barrick D (2006) Use of radars to monitor stream discharge by noncontact methods. Water Resour Res 42(7):1-14

Dale VH, Hughes MJ, Hayes DJ (2016) Climate change and the future of natural disturbances in the central hardwood region. In natural disturbances and historic range of variation (pp. 355-369). Springer International Publishing

Dingman SL (2015) Physical hydrology. Waveland Press, Long grove

Dobriyal P, Qureshi A, Badola R, Hussain SA (2012) A review of the methods available for estimating soil moisture and its implications for water resource management. J Hydrol 458-459:110-117

Egusa T, Ohte N, Oda T, Suzuki M (2013) Relationship between catchment scale and the spatial variability of stream discharge and chemistry in a catchment with multiple geologies. Hydrol Res Lett 7(2):12-17

Ely E (1994) A profile of volunteer monitoring. Volunteer Monitor $6(1): 4$

Emiroglu ME, Bilhan O, Kisi O (2011) Neural networks for estimation of discharge capacity of triangular labyrinth sideweir located on a straight channel. Expert Syst Appl 38(1):867-874

Flener C, Wang Y, Laamanen L, Kasvi E, Vesakoski JM, Alho P (2015) Empirical modeling of spatial 3d flow characteristics using a remote-controlled ADCP system: monitoring a spring flood. Water 7(1):217-247

Flury M, Wai NN (2003) Dyes as tracers for vadose zone hydrology. Rev Geophys 41(1):2-27

Friederich H, Smart PL (1982) The classification of autogenic percolation waters in karst aquifers: a study in GB cave Mendip hills England. Proc Univ Bristol Spelaeol Soc 16(2):143-159

George BA, Adams R, Ryu D, Western AW, Simon P, Nawarathna B (2011) An assessment of potential operational benefits of shortterm streamflow forecasting in the broken catchment, Victoria. In: Proceedings of the 34th World Congress of the International Association for Hydro-Environment Research and Engineering: 33rd hydrology and water resources symposium and 10th conference on hydraulics in water engineering. Engineers Australia, p 2070

Ghodsian M (2003) Supercritical flow over a rectangular side weir. Can J Civ Eng 30:596-600

Gleick PH (ed) (2014) The world's water (vol 8). The biennial report on freshwater resources (vol 8). Island Press, Washington

Gonzalez CA, Chanson H (2007) Experimental measurements of velocity and pressure distributions on a large broad-crested weir. Flow Meas Instrum 18(3):107-113

Gordon ND, McMahon TA, Finlayson BL, Gippel CJ (2004) Stream hydrology: an introduction for ecologists, 2nd edn. Wiley, England

Gordon ND, McMahon TA, Finlayson BL, Gippel CJ, Nathan RJ (2013) Stream hydrology: an introduction for ecologists. Wiley, England

Grant DM, Brian DD (1997) Isco open channel flow measurement handbook, 5th edn. Isco Inc, Lincoln

Greeve FW (1928) Measurement of pipe flow by the coordinate method. Purdue Engineering Experiment Station, Bulletin 32

Greiber T (2009) Payments for ecosystem services: legal and institutional framework. Environmental policy and law paper (No. 78), IUCN

Hamilton AS, Moore RD (2012) Quantifying uncertainty in streamflow records. Can W Resour J 37(1):3-21

Haritashya UK, Singh P, Kumar N, Singh Y (2006) Hydrological importance of an unusual hazard in a mountainous basin: flood and landslide. Hydrol Processes 20(14):3147-3154

Harmel RD, Smith DR, King KW, Slade RM (2009) Estimating storm discharge and water quality data uncertainty: a software tool for monitoring and modeling applications. Environ Model Softw 24(7):832-842

Harpold AA, Mostaghimi S, Vlachos PP, Brannan K, Dillaha T (2006) Stream discharge measurement using a large-scale particle image velocimetry (LSPIV) prototype. Trans ASABE 49(6): 1791-1805

Harrelson CC, Rawlins CL, Potyondy JP (1994) Stream channel reference sites: an illustrated guide to field technique. Gen Tech Rep RM-245. US Department of Agriculture Forest Service Rocky Mountain Forest and Range Experiment Station, Fort Collins

Harwell GR, Asquith WH (2011) Annual peak streamflow and ancillary data for small watersheds in central and western Texas. US Department of the Interior, US Geological Survey

Hauer FR, Lamberti GA (2007) Methods in stream ecology, 2nd edn. Academic Press, San Diego

Hauet A, Creutin JD, Belleudy P (2008) Sensitivity study of largescale particle image velocimetry measurement of river discharge using numerical simulation. J Hydrol 349(1):178-190

Herschy, RW (1978) Accuracy in hydrometry: principles and practices. Wiley, New York, 353-397

Herschy RW (1995) Streamflow measurement. CRC Press, Florida

Herschy RW (2008) Streamflow measurement, 3rd edn. Taylor and Francis, USA

Hess LL, Melack JM, Filoso S, Wang Y (1995) Delineation of inundated area and vegetation along the Amazon floodplain with the SIR-C synthetic aperture radar IEEE. Trans Geosci Remote Sens 33(4):896-904

Hilgersom KP, Luxemburg WMJ (2012) Technical note: how image processing facilitates the rising bubble technique for discharge measurement. Hydrol Earth Syst Sci 16:345-356

Hudson NW (1993) Field measurement of soil erosion. Food and agriculture organization of the United Nations, Rome

Hudson JA (2004) The impact of sediment on open channel flow measurement in selected UK experimental basins. J Flow Measure Instrum 15(1):49-58 
Huntington TG (2006) Evidence for intensification of the global water cycle: review and synthesis. J Hydrol 319:83-95

Immerzeel WW, Droogers P, Jong SMD, Bierkens MFP (2009) Remote sensing of environment large-scale monitoring of snow cover and runoff simulation in Himalayan river basins using remote sensing. Remote Sens Environ 113:40-49

John PH (1978) Discharge measurement in lower order streams. Int Revue Ges Hydrobiol 63(6):731-755

Karr JR (1991) Biological integrity: a long-neglected aspect of water resource management. Ecol Appl 1:66-85

Kitlasten W, Fogg GE (2015) Hydrogeology of a groundwater sustained montane peatland: grass Lake. Calif Wetl Ecol Manag 23(5):827-843

Koblinsky CJ, Clarke RT, Brenner AC, Frey H (1993) Measurement of river level variations with satellite altimetry. W Resou Res 29(6): 1839-1848

Lawson TB (1995) Fundamentals of aquacultural engineering, 2nd edn. Springer, New york

Lee K, Mukai T, Lee DJ, Iida K (2014) Classification of soundscattering layers using swimming speed estimated by acoustic Doppler current profiler. Fish Sci 80(1):1-11

Liu HX, Shao QM, Kang C (2014) Flow characteristics and cavitation effect of the submerged water jet discharged from a central-body nozzle. World J Eng Tech 2:281-288

Lu Y, Lueck RG (1999) Using a broadband ADCP in a tidal channel Part II: turbulence. J Atmos Oceanic Technol 16:1568-1579

Martin EC (2006) Measuring water flow in surface irrigation ditches and gated pipe. Cooperative Extension Pub No AZ1329 Arizona Water Series No 31, The University of Arizona

Mata LJ, Budhooram J (2007) Complementarity between mitigation and adaptation: the water sector. Mitigation Adapt Strateg Glob Chang 12(5):799-807

Mazari RK, Sah MP (2004) Puliyanal cloudburst of July 16, 2003 district Kullu Himachal Pradesh: lesson for policy implementation. Himal Geol 25:153-161

MEA (Millennium Ecosystem Assessment) (2005) Ecosystems and human well-being: policy responses. Island Press, Washington

Mittelbach H, Lehner I, Seneviratne SI (2012) Comparison of four soil moisture sensor types under field conditions in Switzerland. J Hydrol 430-431:39-49

Moore RD (2004) Introduction to salt dilution gauging for streamflow measurement-part 2. Constant-rate Inject 8(1):11-15

Moran D, Dann S (2007) The economic value of water use: implications for implementing the water framework directive in Scotland. J Env Manage 87:484-496

Mueller DS, Wagner CR (2009) Measuring discharge with acoustic Doppler current profilers from a moving boat. US Geological Survey Techniques and Methods 3A:22

Muste M, Yu K, Spasojevic M (2004) Practical aspects of ADCP data use for quantification of mean river flow characteristics; part I: moving-vessel measurements. Flow Measur Instrum 15(1):1-16

Mutz M, Kalbus E, Meinecke S (2007) Effect of in-stream wood on vertical water flux in low-energy sand bed flume experiments. Wat Resour Res 43:10

Naithani AK, Joshi V, Prasad C (2001) Investigation on the impact of cloudburst in the Tehri district Uttaranchal. J Geol Soc India 60:573-578

Najafi MR, Moradkhani H, Piechota TC (2012) Ensemble streamflow prediction: climate signal weighting methods vs climate forecast system reanalysis. J Hydrol 442:105-116

Oberg KA, Mueller DS (2007) Validation of streamflow measurements made with acoustic Doppler current profilers. J Hydraul Eng 133(12):1421-1432

Otz MH, Otz HK, Otz I, Siegel DI (2003) Surface water/groundwater interaction in the Piora Aquifer Switzerland: evidence from dye tests. Hydrogeol J 11:228-239
Papa F, Bala SK, Pandey RK, Durand F, Gopalakrishna VV, Rahman A, Rossow WB (2012) Ganga-Brahmaputra river discharge from Jason-2 radar altimetry: an update to the long-term satellitederived estimates of continental freshwater forcing flux into the Bay of Bengal. J Geophys Res: oceans (1978-2012):117(C11)

Parker GW, Armstrong DS, Richards TA (2004) Comparison of methods for determining streamflow requirements for aquatic habitat protection at selected sites on the Assabet and Charles Rivers, Eastern Massachusetts, 2000-02. US Geological Survey Scientific Investigations Report 2004-5092:72

Peltz J, Schwartz J (2008) Grid-direct low-power microhydro systems. Home Power:126

Peterson M, Cromwell CF (1993) Measuring irrigation water in a ditch stream or reservoir. University of Missouri Extension: G1681

Pfeffer MJ, Wagenet LP (2007) Volunteer environmental monitoring knowledge creation and citizen-scientist interaction. In Pretty J, Ball A et al. The Sage handbook of environment and society. Sage Publication, London

Prasad AK (2000) Particle image velocimetry. Curr Sci 79(1):51-60

Qureshi A, Dobriyal P, Badola R, Hussain SA (2012) A review of protocols used for assessment of carbon stock in forested landscapes. Environ Sci Policy 16:81-89

Reddy SM, McDonald RI, Maas AS, Rogers A, Girvetz EH, North J, DiMuro JL (2015) Finding solutions to water scarcity: incorporating ecosystem service values into business planning at The Dow Chemical Company's Freeport, TX facility. Ecosystem Services 12:94-107

Revilla-Romero B, Thielen J, Salamon P, De Groeve T, Brakenridge GR (2014) Evaluation of the satellite-based global flood detection system for measuring river discharge: influence of local factors. Hydrol Earth Syst Sci 18(11):4467-4484

Rickard C, Day R, Purseglove J (2003) River weirs- good practice guide. R\&D Publication, Bristol UK

Rohwer C (1943) Discharge of pipes flowing partly full. Civil Engineering, ASCE

Ryckborst H, Christie RO (1977) Feasibility of electromagnetic streamflow measurements using the earth's field. Hydrol Sci J 22(26):241-255

Salguero L, Quinones A, Ackerman L (2008) Wastewater flow management. US Environmental Protection Agency Science and Ecosystem Support Division, Georgia

Şengörür B, Dede C, Doğan E (2014) The examination of the performances of methods used in separating the total streamflow in different rivers. Geofizika 31(1):1-12

Shieh C, Jan C, Tsai Y (1996) A numerical simulation of debris flow and its application. Nat Hazards 13(1):39-54

Shope CL, Bartsch S, Kim K, Kim B, Tenhunen J, Peiffer S, Park J, Ok SY, Fleckenstein J, Koellner T (2013) A weighted, multimethod approach for accurate basin-wide streamflow estimation in an ungauged watershed. J Hydrol 494:72-82

Singh VP (2003) On the theories of hydraulic geometry. Inter J Sediment Res 18(3):196-218

Slate AC (2014) Water geopolitics in central Asia: case study-future implications of Rogun Hydropower Plant Europolis. J Politic Sic Theo 8(1):51-73

Smith LC (1997) Satellite remote sensing of river inundation area stage and discharge: a review. Hydrol Process 11:1427-1439

Smith M, de Groot D, Perrot-Maîte D, Bergkamp G (2006) Payestablishing payments for watershed services. IUCN Reprint, Gland

Soupir ML, Mostaghimi S, Mitchem CE (2009) A comparative study of stream-gaging techniques for low-flow measurements in two Virginia tributaries. J Am W Resour Associ 45(1):110-122

Stamhuis EJ (2006) Basics and principles of particle image velocimetry (PIV) for mapping biogenic and biologically relevant flows. Aquat Ecol 40(4):463-479 
Tan ML, Latif AB, Pohl C, Duan Z (2014) Streamflow modelling by remote sensing: a contribution to digital earth. IOP conference series: earth and environmental science (Vol 18, No 1, p 012060), IOP Publishing

Tauro F, Olivieri G, Petroselli A, Porfiri M, Grimaldi S (2016) Flow monitoring with a camera: a case study on a flood event in the Tiber river. Environ Monit Assess 188(2):1-11

Ticehurst CJ, Bartsch A, Doubkova M, Van Dijk AIJM (2009) Comparison of ENVISAT ASAR GM, AMSR-E passive microwave, and MODIS optical remote sensing for flood monitoring in Australia. Earth Observation and Water Cycle Conference, Frascati, Italy

Tobias CR, Harvey JW, Anderson IC (2001) Quantifying groundwater discharge through fringing wetlands to estuaries: seasonal variability methods comparison and implications for wetlandestuary exchange. Limnol Oceanogr 46(3):604-615

UN (United Nations) (2011) Challenges and opportunities for water in the transition to a green economy international UN-water conference water in the green economy in practice: towards Rio+20, 3-5 October 2011

USDA (United States Department of Agriculture) 2001 Water measurement manual: a water resources technical publication. United States Department of the Interior Bureau of Reclamation, United State of America

USFWS (United States Fish and Wildlife Services)2006 Water measurement Mountain-Prairie region. Water Resources Division, United State of America

USGS (United States Geological Survey) (2007) How streamflow is measured? The discharge measurement, US Department of the Interior, United State of America
Van Gent MRA, de Vries JVT, Coeveld EM, De Vroeg JH, Van de Graaff J (2008) Large-scale dune erosion tests to study the influence of wave periods. Coastal Eng 55(12):1041-1051

van Leer BR (1924) The California pipe method of water measurement. Engineering News Record, August 21, 2004

Visbeck M (2001) Deep velocity profiling using lowered acoustic Doppler current profilers: bottom track and inverse solutions. J Atm Oceanic Tech 19:794-807

Vogel RM, Lall U, Cai X, Rajagopalan B, Weiskel PK, Hooper RP, Matalas NC (2015) Hydrology: the interdisciplinary science of water. Water Resour Res 51(6):4409-4430

Ward DP, Hamilton SK, Jardine TD, Pettit NE, Tews EK, Olley JM, Bunn SE (2013) Assessing the seasonal dynamics of inundation, turbidity, and aquatic vegetation in the Australian wet-dry tropics using optical remote sensing. Ecohydrology $6(2): 312-323$

Watson CC, Holmes RR Jr, Biedenharn DS (2013) Mississippi river streamflow measurement techniques at St. Louis, Missouri. J Hydraul Eng 139(10):1062-1070

Weight WD, Sonderegger JL (2001) Manual of applied field hydrogeology. McGraw-Hill, New York

Woodward G, Perkins DM, Brown LE (2010) Climate change and freshwater ecosystems: impacts across multiple levels of organization. Phil Trans R Soc B 365:2093-2106

Xu K, Zhang J, Watanabe M, Sun C (2004) Estimating river discharge from very high-resolution satellite data: a case study in the Yangtze River China. Hydrol Process 18:1927-1939

Yan Y (1996) Mass flow measurement of bulk solids in pneumatic pipelines. Meas Sci Technol 7:687 